Check for updates

Cite this: Mater. Adv., 2021, 2, 2989

Received 28th September 2020, Accepted 21st March 2021

DOI: 10.1039/d0ma00743a

rsc.li/materials-advances

\title{
Compatibility assessment of solid ceramic electrolytes and active materials based on thermal dilatation for the development of solid-state batteries
}

\author{
M. Bertrand, ${ }^{a}$ S. Rousselot, ${ }^{a}$ D. Aymé-Perrot ${ }^{b}$ and M. Dollé ${ }^{\star a}$
}

\begin{abstract}
Assembling an all ceramic solid-state battery (ACSSB) using inorganic oxide electrolytes is challenging. The battery must have a continuous layered structure with a thin dense electrolyte separator and interfaces between active material (AM) and ceramic electrolytes (CE) must be optimized within the electrodes to minimize polarization. This is generally achieved using high temperature processing. Selecting suitable AM and CE materials is a complex task that requires a thorough knowledge of the electrochemical behavior of each material in addition to a deep understanding of the thermal and chemical compatibility with other components of the cell. Mismatched thermal expansion coefficients (TECS) of the various layers and materials in the device can lead to cracks during the sintering step and upon cooling that dramatically affect the battery performance. Moreover, it must be certain that no reaction occurs between active materials and electrolytes in the sintering temperature range. These are two key parameters to address for the development of all ceramic solid-state batteries. High temperature $\mathrm{x}$-ray diffraction ( $\mathrm{HT}$-XRD) has been used to determine TECs of various well-known oxide $A M$ and $C E$ up to $1000{ }^{\circ} \mathrm{C}$. It is shown that TECs of typical CEs vary between $-1 \times 10^{-5} \mathrm{~K}^{-1}$ to $4 \times 10^{-5} \mathrm{~K}^{-1}$ but still remain more stable than that of conventional AMs, which are higher on average. On the basis of TEC, lower mismatch is found for different couples. Chemo-thermal compatibility is then investigated for couples with $\mathrm{LiNi}_{0.5} \mathrm{Mnn}_{1.5} \mathrm{O}_{4}$ (LNMO) material. It is determined that mixing $\mathrm{Li}_{0.33} \mathrm{La}_{0.55} \mathrm{TiO}_{3}$ (LLTO) with LNMO might be an interesting avenue for sintering ACSSB.
\end{abstract}

\section{Introduction}

Lithium ion batteries (LIBs) are the most commonly used batteries for mobile storage because of their high energy density, long cycle life and relatively low cost. Typical LIBs contain organic liquid electrolytes. ${ }^{1}$ Despite several advantages of this type of electrolyte (high conductivity and easy formability), solid electrolytes may represent an avenue for future advances in LIB technology, including development for electric vehicles and stationary applications. Safety and energy density are among the main obstacles faced by liquid electrolytes for the most stringent LIB applications. Organic liquid electrolytes are subject to catch fire due to overheating or short-circuiting. ${ }^{2}$ Nowadays, the production of LIBs for mobile applications is well controlled and accidents are extremely rare (but not nonexistent). However, the large number of LIBs that are often packed together require higher safety standards as a result of

\footnotetext{
${ }^{a}$ Département de Chimie, Université de Montréal, 1375 Avenue Thérèse-Lavoie-Roux, Montréal, QC H2V ов3, Canada

${ }^{b}$ Total SA, La Défense, 2, Pl. Jean Miller, 92078 Paris, France
}

possible chain reactions. ${ }^{3}$ Ceramic oxide electrolytes may present a solution for safer and more energy density systems because of their non-flammability and wide potential window. Inorganic oxide electrolytes have relatively good conductivities $\left(10^{-5}-10^{-3}\right.$ $\mathrm{S} \mathrm{cm}^{-1}$ ) at room temperature, high mechanical strength, and high chemical stability. ${ }^{4}$ However, assembling an all ceramic solid-state battery with an inorganic oxide electrolyte is challenging as it requires a deep knowledge of the electrochemical, chemical and thermal behavior of each component of the cell. ${ }^{2-7}$

The battery must be a continuous layered structure of ceramics with a thin dense electrolyte separator, in order to minimize polarization. ${ }^{8}$ Preparing such batteries requires mixing solid electrolytes with active materials and conductive fillers in the electrode part to ensure optimized interfaces between active material and electrolytes. This is often achieved with oxide-based materials via high temperature processing between 600 and $1200{ }^{\circ} \mathrm{C}^{8-13}$ In the electrolyte part itself, sintering at high temperature allows the ceramic grains to merge, this leads to a reduction of overall porosity. This favors the formation of an efficient lithium ion pathway between the electrolyte particles and the two composite electrodes. It can be noticed than co-sintering of 
CE and AM material are not the only way to prepare oxide based ASSB in the literature. For example, infiltration of AM in induced CE porosities or use of additives to allow "cold sintering" are other ways. ${ }^{14,15}$ Besides, most of the works in literature are focused on "solvent assisted" ASSB preparation that consists of the cold mixing” of CE and AM with a conducting polymer dissolved in a solvent, conductive fillers to produce composite electrode. ${ }^{16,17}$ Even though the thermal compatibility is not an issue for these systems, the chemical and electrochemical compatibility issue remain and is largely addressed.

When considering continuous layered structure of ceramics, sintering is the most critical step for material compatibility. As processing temperatures are high, the thermodynamic stability of mixed materials can be an issue and it needs to be considered. When instability is expected, the reaction kinetic may help to minimize the chemical reactivity between the electrolyte ceramic and the active material, which will then depend on the sintering technique used and the processing time at high temperature. For example, techniques like Spark Plasma sintering has been preferred due to the fast sintering which requires only few minutes to happen. The products formed are most of the time ioninsulating and electrochemically inactive. ${ }^{18}$ In that case, chemical reaction between the active material and the electrolyte should be avoided during thermal processing. Moreover, during cool down, cracks due to thermal dilatation can happen. Cracks decrease the mechanical properties of the battery and are obstacles to Li-ion displacement, so they should also be avoided. ${ }^{19}$ Because of that, thermal and chemical compatibility between ceramic electrolytes and active materials must be studied and fully understood.

However, forming multilayer ceramic devices is not new. Ceramic electrolytes are already widely used in solid oxide fuel cells (SOFC). While electroles in lithium ion batteries conduct lithium ions, unlike electrolytes in SOFC which conduct oxygen ions, similar materials can be used in both devices. The preparation of multilayer fuel cell electrolytes has been extensively researched in the past. ${ }^{20-24}$ For example, the effects of stress generated by thermal dilatation have already been addressed in SOFCs as these devices are operated at elevated temperatures. Similarly, to all ceramic battery cells, cracks within the fuel cells are highly detrimental. The primary driving force of crack formation during the fabrication of hybrid ceramics is the stress that is caused by a mismatch in the thermal expansion coefficients $\alpha$ (TEC) of the various layers/materials. ${ }^{20}$ TEC is defined by eqn (1):

$$
\alpha=\frac{1}{L} \frac{\mathrm{d} L}{\mathrm{~d} T}
$$

Where $L$ is a length in a direction, such as a cell parameter. Upon cooling, the stress generated $(\sigma)$ between an active and solid electrolyte material can be roughly evaluated by eqn (2) where isotropic elastic behavior of mixed materials is assumed. ${ }^{25}$

$$
\sigma=\frac{\Delta \alpha \Delta T}{\frac{1}{E_{\text {a.m. }}}+\frac{1}{E_{\text {e.m. }}}}
$$

Where $\Delta \alpha$ is the TEC mismatch between the active material and the solid electrolyte, $\Delta T$ is the difference between the sintering temperature and the room temperature, $E_{\text {a.m. }}$ and $E_{\text {e.m. }}$ are the elastic moduli of the active material and the electrolyte material. More accurate methods exist for better prediction of interfacial stresses, such as the Finite Element Analysis which is a model of failure based on the Weibull statistics. ${ }^{26}$ Models also depend on the cell geometry (planar or tubular), and on the microstructure of materials. ${ }^{20,27-31}$ The same methodology used in SOFC research can also be applied for the selection of solid oxide electrolytes and active material for the assembly of all solid-state batteries. However, literature on the TECs for lithium battery materials is scarce. The assessment of the TECs of typical solid electrolytes and active materials is therefore a valuable tool for the careful selection of battery components.

For SOFC devices, the TEC is usually measured using dilatometry. ${ }^{32}$ In this work, high temperature X-ray diffractometry (HT-XRD) is chosen such that precise measurements can be directly related to the crystallographic structure of the sample. Moreover, with HT-XRD, the dependence of the TEC on the crystallographic axis can be assessed. It is important to take this parameter into account, because strong anisotropy could result in microcracking when the grain size exceeds a certain critical value during sintering. ${ }^{33}$ In-situ XRD also allows structural changes or parasitic reactions that occur with changing temperature to be closely followed.

The aim of this article is to suggest an effective method for the selection of compatible materials for the sintering process of all solid-state ceramic batteries. In the present paper, typical solid electrolytes and active materials for use in lithium ion batteries are studied using HT-XRD with a focus on their respective TECs. Thermal stabilities of three couples are evaluated based on the minimal mismatch of the mean TEC between the AM and the CE. These materials are tested in a classical furnace. The results presented here are intended to be used as a reference guide for battery ceramists.

\section{Materials and method}

\section{Materials and synthesis}

All CE materials were synthesized in the laboratory. Oxide CEs were prepared via solid-state processes while $\mathrm{Li}_{1.3} \mathrm{Al}_{0.3} \mathrm{Ti}_{1.7}\left(\mathrm{PO}_{4}\right)_{3}$ (LATP) was produced by hydrothermal synthesis.

Prior to synthesizing, $\mathrm{La}_{2} \mathrm{O}_{3}$ was fired at $900{ }^{\circ} \mathrm{C}$ overnight to remove carbonate due to its hygroscopic nature.

Phase pure $\mathrm{Li}_{1.3} \mathrm{Al}_{0.3} \mathrm{Ti}_{1.7}\left(\mathrm{PO}_{4}\right)_{3}$ (LATP) was produced via a hydrothermal process ${ }^{34}$ using intermediate product $\mathrm{Ti}_{2} \mathrm{O}\left(\mathrm{PO}_{4}\right)_{2}$ obtained from $\mathrm{TiO}_{2}$ (99\% Sigma Aldrich) stirred in an aqueous solution containing Phosphoric acid (85\%) at $160{ }^{\circ} \mathrm{C}$. $\mathrm{Al}(\mathrm{OH})_{3}$ (Fisher Scientific) and $\mathrm{LiOH}$ (98\% Sigma Aldrich) were added after cooling at $80{ }^{\circ} \mathrm{C}$. The obtained suspension was dried, ground and finally heated to $900{ }^{\circ} \mathrm{C}$ for $6 \mathrm{~h}$.

Polycrystalline $\mathrm{Li}_{0.33} \mathrm{La}_{0.55} \mathrm{TiO}_{3}$ (LLTO) was prepared by solid state reaction. In order to synthetize $10 \mathrm{~g}$ of product, stoichiometric amounts of $\mathrm{La}_{2} \mathrm{O}_{3}$ and $\mathrm{TiO}_{2}$ and $10 \mathrm{~mol} \%$ excess of $\mathrm{Li}_{2} \mathrm{CO}_{3}$ (to prevent lithium vaporization from occurring during thermal treatments) were mixed in isopropyl alcohol via ball 
milling for $24 \mathrm{~h}$ at $700 \mathrm{rpm}$ with 12 balls of $\mathrm{ZrO}_{2}(10 \mathrm{~mm}$ diameter) in a Fritsch planetary mill Pulverisette. After solvent evaporation, the powder was calcined in an alumina crucible at $1100{ }^{\circ} \mathrm{C}$ for $1 \mathrm{~h}$ (rate of $20{ }^{\circ} \mathrm{C} \mathrm{min}{ }^{-1}$, heating and cooling). The resultant powder was ground using a high energy ball mill (SPEX Mill) using $3.15 \mathrm{~g}$ of $\mathrm{ZrO}_{2}$ ball per gram of powder with $2 \mathrm{wt} \%$ of stearic acid. Powder sieved below $45 \mu \mathrm{m}$ is used in order to press a pellet (diameter $=10 \mathrm{~mm}$ ) under a pressure of $600 \mathrm{MPa}$ for 30 minutes. The pellet was sintered at $1200{ }^{\circ} \mathrm{C}$ for $5 \mathrm{~h}$ (heating rate of $10^{\circ} \mathrm{C} \mathrm{min}^{-1}$ and cooling rate of $30^{\circ} \mathrm{C} \mathrm{min}^{-1}$ ) using the powder bed technique.

Al-doped $\mathrm{Li}_{6.5} \mathrm{Al}_{0.25} \mathrm{La}_{2.92} \mathrm{Zr}_{2} \mathrm{O}_{12}$ (AL-LLZO) was prepared via a solid-state process. First, stoichiometric amounts of $\mathrm{Al}\left(\mathrm{NO}_{3}\right) \cdot 9 \mathrm{H}_{2} \mathrm{O}, \mathrm{ZrO}_{2}$ and $\mathrm{La}_{2} \mathrm{O}_{3}$ and $10 \mathrm{~mol} \%$ excess of $\mathrm{LiOH} \cdot \mathrm{H}_{2} \mathrm{O}$ were ground in a high energy ball mill before being degassed for $12 \mathrm{~h}$ at $600{ }^{\circ} \mathrm{C}$. The degassed mixture was then milled for a second time. Part of the resulting powder was pelletized and then placed in a $\mathrm{ZrO}_{2}$ crucible using the powder bed technique at $900{ }^{\circ} \mathrm{C}$ for $10 \mathrm{~h}$.

Three grades of $\mathrm{AM}$ layered oxides $\mathrm{LiNi}_{x} \mathrm{Mn}_{y} \mathrm{Co}_{z} \mathrm{O}_{2}$ were provided by Targray, Canada: $\mathrm{LiNi}_{0.33} \mathrm{Mn}_{0.33} \mathrm{Co}_{0.33} \mathrm{O}_{2}$ (NMC111), $\mathrm{LiNi}_{0.5} \mathrm{Mn}_{0.3} \mathrm{Co}_{0.2} \mathrm{O}_{2}$ (NMC532), and $\mathrm{LiNi}_{0.80} \mathrm{Co}_{0.15} \mathrm{Al}_{0.05} \mathrm{O}_{2}$ (NCA). Spinel $\mathrm{LiNi}_{0.5} \mathrm{Mn}_{1.5} \mathrm{O}_{4}$ (LNMO) from Sigma Aldrich was also investigated. $\mathrm{LiFePO}_{4}$ (LFP, P2) was supplied by Johnson Matthey. $\mathrm{LiFe}_{0.25} \mathrm{Mn}_{0.75} \mathrm{PO}_{4}$ (LFMP) was synthetized by melt process. ${ }^{35} \mathrm{Fe}$ metal (Atomet 1001HP from Rio Tinto-Quebec Metal Powder (QMP)), $\mathrm{LiPO}_{3}$ made from the dehydration of $\mathrm{LiH}_{2} \mathrm{PO}_{4}$ (from Sichuan Tianqi Lithium Industries Inc., China (TQC)), $\mathrm{Fe}_{2} \mathrm{O}_{3}$ (99\%, Sigma Aldrich) and $\mathrm{MnCO}_{3}(99.5 \%$, CSC) were used as precursors.

LFP was chemically delithiated into $\mathrm{FePO}_{4}$ (FP) using acetic acid and hydrogen peroxide as described by Lepage et al. ${ }^{36}$

\section{X-ray diffraction measurements}

Prior to performing any experiments, the microstructure of all materials was analyzed using a Bruker Diffractometer D8 Advance. HT-XRD were carried out at increasing temperature from 30 to $1000{ }^{\circ} \mathrm{C}$ (maximum) every $100{ }^{\circ} \mathrm{C}$ using the Bruker D8 instrument with an integrated furnace. The sample was placed in an alumina crucible. After reaching the given temperature with a heating rate of $10{ }^{\circ} \mathrm{C} \mathrm{min}{ }^{-1}$, the temperature was held for 5 minutes. Temperature uncertainty is about $\pm 1{ }^{\circ} \mathrm{C}$. All XRD data were collected in the $2 \theta$ range of $10 / 15-90^{\circ}$ with a $\mathrm{CuK} \alpha$ radiation $(\lambda=0.15060 \mathrm{~nm})$, a step size of $0.02^{\circ}$ and a $1 \mathrm{~s}$ per step rate. The applied voltage and current were $40 \mathrm{kV}$ and $40 \mathrm{~mA}$, respectively. XRD data was also collected at $30{ }^{\circ} \mathrm{C}$ after fast cooling. All measurements were conducted under air except for LFP and LFMP which were heated under argon to avoid oxidation of $\mathrm{Fe}^{2+}$ and $\mathrm{Mn}^{2+}$. The $\mathrm{FePO}_{4}$ measurement was also conducted under argon to avoid calcination of the carbon coating which is necessary for good electrochemical performance. Phosphateolivine materials are heated only to $800{ }^{\circ} \mathrm{C}$ in order to avoid fusion. ${ }^{37}$ All other materials were heated to $1000{ }^{\circ} \mathrm{C}$. Lithium evaporation is known to happen at high temperature, ${ }^{38-41}$ however, materials are exposed to temperature superior to $800{ }^{\circ} \mathrm{C}$ for no more than 4 hours (considering the heating ramp and cooling) in static atmosphere but still reach a steady temperature. Such short exposition time limits potential lithium loss during experiment.

XRD of mixed material (50/50 vol\%) were performed in the $2 \theta$ range of $10-80^{\circ}$ using same instrument and parameters after ex situ heat treatment at a given temperature for 1 and $10 \mathrm{H}$.

\section{Data analysis}

GSAS-II $^{42}$ was used in order to extract all the cell parameters. The peak profile shape was fitted using a pseudo-Voigt profile. Rietveld refinement was performed when the CIF file was available; otherwise, Pawley refinement was done. Both methods have limited impact on the measured cell parameters. Contrary to Pawley refinement, Rietveld refinement consider the chemical structure of the material. The fitted parameters were: scale factor, sample displacement, unit cell parameters, size of the crystallites, microstrain and relative intensities. Atomic displacement parameters $U_{\text {iso }}$ and the position of heavy atoms were determined when Le Bail refinement was performed. Prior to the analysis of GSAS-II, standard deviations for cell parameters were always below $1 \times 10^{-3} \mathrm{~nm}$. According to eqn (1), TECs are calculated using the approximation $\mathrm{d} T \approx \Delta T$ :

$$
\alpha_{T_{i}}=\frac{1}{L_{T_{i}}} \frac{L_{T_{i}}-L_{T_{i-1}}}{T_{i}-T_{i-1}}
$$

Where $T_{i}$ is the temperature at which the diffractogram $i$ was obtained.

Tables containing resulting $R_{\mathrm{wp}}$, cells parameters, microstrain coefficient and crystallite size for each material and temperature are available in the ESI1, Table 1.

\section{Results and discussion}

Rietveld refinement and Pawley refinement analyses are used to determine the structural changes within the materials during the heating process. Using the determined cell parameters and eqn(1), TECs as a function of temperature were calculated for CE and AM.

\section{Solid oxide electrolytes}

Perovskite material LLTO. The perovskite type $\mathrm{Li}_{3 x} \mathrm{La}_{(2 / 3-x)(1 / 3-2 x)^{-}}$ $\mathrm{TiO}_{3}(0.04<x<0.16)$ (LLTO) exhibits a conductivity of $1.53 \times$ $10^{-3} \mathrm{~S} \mathrm{~cm}^{-1}$ (bulk) at ambient temperature. LLTO requires very high temperatures to increase its grain boundary conductivity (total conductivity of $5 \times 10^{-4} \mathrm{~S} \mathrm{~cm}^{-1}$ was achieved at a sintering temperature of $1450{ }^{\circ} \mathrm{C}^{43}$ ) and its synthesis is airsensitive. ${ }^{44,45}$ Diffractograms depending on the temperature between $30{ }^{\circ} \mathrm{C}$ and $1000{ }^{\circ} \mathrm{C}$ are shown in Fig. 1a as an example. No impurity is found in the XRD pattern of $\mathrm{Li}_{0.33} \mathrm{La}_{0.55} \mathrm{TiO}_{3}$ $(x=0.11)$ up to $900{ }^{\circ} \mathrm{C}$. A $2 \times 2 \times 2$ supercell of the perovskite unit cell is used to fit the diffractometer pattern because broad and weak diffraction peaks arising from a superlattice are observed. They correspond to the ordering of the cation vacancies (layers (001) of La-rich and La-poor A-type sites alternating ${ }^{46}$ and to an anti-phase rotation of the $\mathrm{TiO}_{6}$ octahedra along the $\mathrm{a}$ and $\mathrm{b}$ axes. ${ }^{47}$ Structure is described using a global average picture with the orthorhombic space group $\mathrm{Cmmm}$ based on work by 

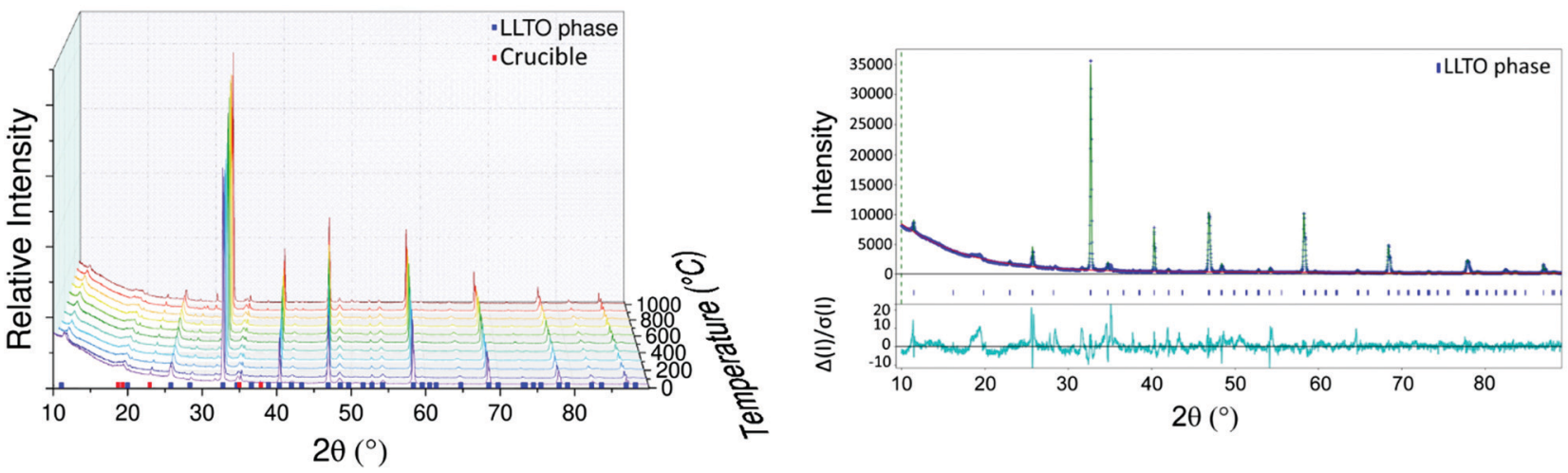

Fig. 1 (a) Diffractograms of LLTO between 30 and $1000{ }^{\circ} \mathrm{C}$ and (b) fit of diffractogram of LLTO at $30{ }^{\circ} \mathrm{C}$ after cooling using Le Bail refinement

Cheng et al. because it provides a lower $R_{\mathrm{wp}}$ compared to the tetragonal $P 4 / \mathrm{mmm}$ model $\left(8.10 \%\right.$ vs $9.87 \%$ at $30{ }^{\circ} \mathrm{C}$ and approximately $2 \%$ less on all the temperature range). The result of the fit at $30{ }^{\circ} \mathrm{C}$ after cooling using the Le Bail refinement is shown in Fig. 1b. Main residues are due to the alumina crucible. Only a small amount of unidentified impurities or new ordering appear at $900{ }^{\circ} \mathrm{C}$ (particularly at $2 \theta=30^{\circ}$ ), but the structure is still well conserved. The same structure and relative intensities without the impurities are recovered after cooling.

The LLTO cell parameters (Fig. 2a) at $30{ }^{\circ} \mathrm{C}$ are $a=7.753(1) \AA$, $b=7.803(1)$ and $c=7.706(1) \AA$. These values are in agreement with literature values. ${ }^{47,48}$ Parameters increase linearly to $a=$ 7.818(1) $\AA, b=7.864(1)$ and $c=7.778(1) \AA$ at $900{ }^{\circ} \mathrm{C}$. An orderdisorder transition of $\mathrm{La}^{3+}$ ions occurs at $1000{ }^{\circ} \mathrm{C}$ where the $b$ and $c$ parameters tend to be closer to the $a$ parameter with $a=7.827(1) \AA, b=7.840(1) \AA$ and $c=7.821(1) \AA .{ }^{48}$ After cooling, the high temperature phase is preserved with a structure closer to the cubic one than to that of the initial material with $a=$ 7.742(1) $\AA, b=7.768(1) \AA$ and $c=7.756(1) \AA$ which demonstrates the importance of cooling rate to conserve the more conductive disordered phase ${ }^{49}$ as well as the good reversibility of the LLTO unit cell (volume of the unit cell is conserved).

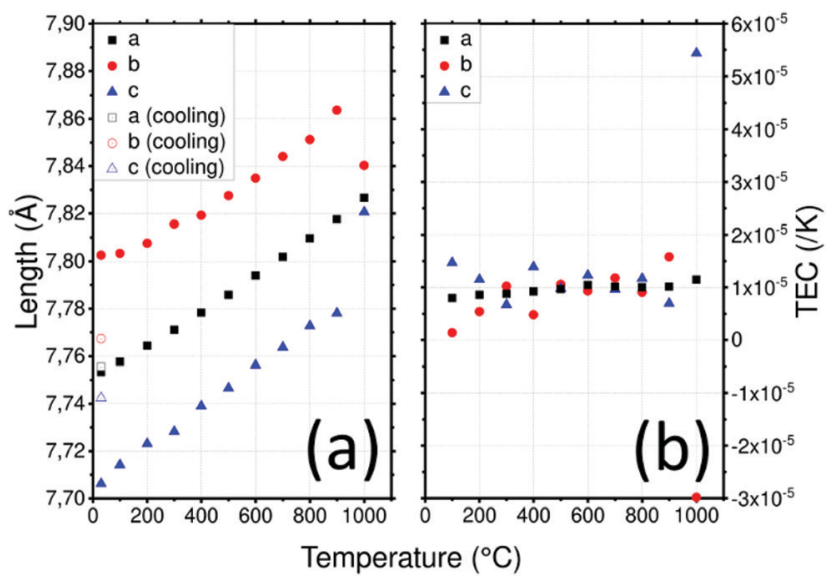

Fig. 2 (a) Lattice parameters of LLTO depending on the temperature in air and (b) thermal expansion coefficient (TEC) as a function of temperature and the crystallographic axis of LLTO.
XRD was used to determine the TEC of LLTO as shown in Fig. 2b. The TEC was found to remain relatively constant at about $1 \times 10^{-5} \mathrm{~K}^{-1}$ until $900{ }^{\circ} \mathrm{C}$. There is no evidence of differences between the evolution of the TEC along the $a, b$ and $c$ directions which is consistent with the fact that the only difference between the axes is the ordering of La atoms and the rotation of the $\mathrm{TiO}_{6}$ octahedra. At $1000{ }^{\circ} \mathrm{C}$ the order-disorder phase transition is responsible for the huge anisotropy of TECs along the $\mathrm{b}$ and $\mathrm{c}$ directions: these become $-3 \times 10^{-5} \mathrm{~K}^{-1}$ and $5.5 \times 10^{-5} \mathrm{~K}^{-1}$ respectively.

Nasicon material LATP. $\mathrm{Li}_{1.3} \mathrm{Al}_{0.3} \mathrm{Ti}_{1.7}\left(\mathrm{PO}_{4}\right)_{3}$ (LATP), a part of the NASICON-type structure family and it crystallizes as $\mathrm{LiTi}_{2}\left(\mathrm{PO}_{4}\right)_{3}$ in the $R \overline{3} c$ space group.

Diffractogram in the range of temperatures between $30{ }^{\circ} \mathrm{C}$ and $1000{ }^{\circ} \mathrm{C}$ and result of the fit at $30{ }^{\circ} \mathrm{C}$ using Le Bail refinement are shown in Fig. S1 (ESI1). The densification of LATP occurs at least at $700{ }^{\circ} \mathrm{C} .{ }^{50}$ Small amount of $\mathrm{LiTiPO}_{5}$ are identified in the diffractometer pattern of LATP. LATP is stable up to $800{ }^{\circ} \mathrm{C}$ where intensities drop and full width at half maximum (FWHM) increase as a result of a decrease in the measured crystallite size from 250 to $120 \mathrm{~nm}$. XRD analysis allows the evolution of the crystallite size to be followed when it is inferior to $200 \mathrm{~nm}$, even if absolute values must be taken carefully, this evolution is significant and explained below.

LATP cell parameters in air, reported in (Fig. 3a), vary from $a=8.505(1) \AA$ and $c=20.800(1) \AA$ at $30{ }^{\circ} \mathrm{C}$ to $8.505(1) \AA$ and 21.430(1) $\AA$ at $1000{ }^{\circ} \mathrm{C}$, respectively using the hexagonal unit cell. Cell parameter $a$ remains constant over the temperature range contrary to $c$ which varies significantly. These cell parameters are in good agreement with the experiment conducted under vacuum by Monchak et al. up to $800{ }^{\circ} \mathrm{C}$ : this means that LATP is stable and does not release oxygen at high temperatures. ${ }^{51}$ After cooling, the cell parameters are recovered with $a=8.507(2) \AA$ and $c=20.800(3) \AA$. The different evolutions of the lattice parameters with temperature are likely to lead to significant anisotropy which can be quantified by calculating the TEC.

A strong anisotropy between $a$ and $c$ axis is visible for the TEC of the LATP material in Fig. $3 \mathrm{~b}: 3.1 \times 10^{-5} \mathrm{~K}^{-1}$ along the $c$ axis and about $1 \times 10^{-6} \mathrm{~K}^{-1}$ along the $a$ axis up to $1000{ }^{\circ} \mathrm{C}$. Critical grain size due to mismatch of the TEC was estimated to be about $1 \mu \mathrm{m} .{ }^{50}$ Because of this high anisotropy, the reduction 


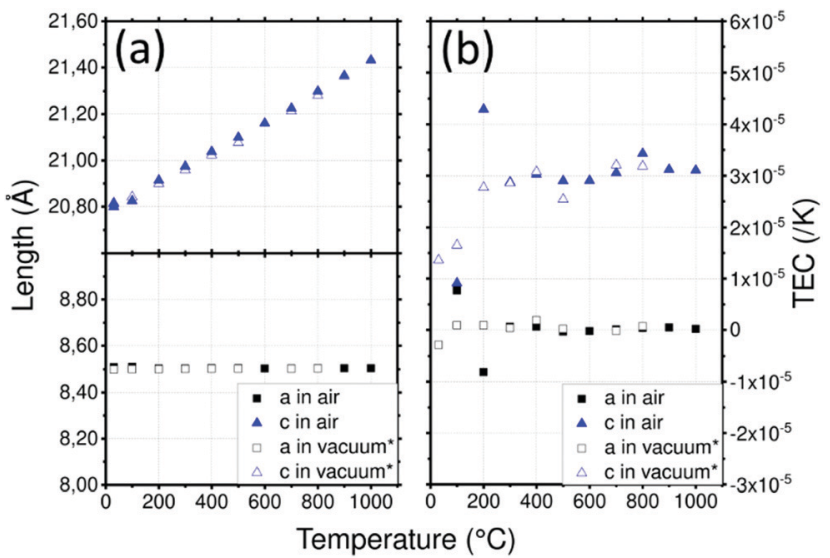

Fig. 3 (a) Lattice parameters of LATP depending on the temperature and (b) thermal expansion coefficient (TEC) as a function of temperature and the crystallographic axis of LATP. (*) Data from Monchak et al. ${ }^{51}$

of crystallite size observed above $800{ }^{\circ} \mathrm{C}$ can be attributed to cracks within grains leading to pulverization. ${ }^{50}$ As cracks are not suitable for ionic conductivity, the sintering of materials containing LATP should be performed carefully. Data reported by Monchak et al. were used to calculate the TEC of LATP under vacuum and are compared to the present analysis performed in air. The results from experiments performed in air or vacuum are very similar and confirm the non-influence of the atmosphere on LATP.

Garnet material Al-LLZO. In its cubic phase (space group $I \overline{4} 3 d$ ), Al-LLZO exhibits high ionic bulk conductivity of $10^{-4}$ to $10^{-3} \mathrm{~S} \mathrm{~cm}^{-1}$ at ambient temperature and a wide potential window, and it is chemically stable versus metallic lithium. ${ }^{52}$ Nevertheless, Al-LLZO has interfacial issues: it is unstable in air and it reacts with $\mathrm{H}_{2} \mathrm{O}$ and $\mathrm{CO}_{2}$, consequently $\mathrm{Li}_{2} \mathrm{CO}_{3}$ is easily formed on the surface, reducing the total conductivity. ${ }^{53}$ Moreover, Al-LLZO must be sintered at high temperature (about $\left.1200{ }^{\circ} \mathrm{C}\right) .{ }^{54}$ Diffractogram in the range of temperatures between $30{ }^{\circ} \mathrm{C}$ and $1000{ }^{\circ} \mathrm{C}$ and result of the fit at $30^{\circ} \mathrm{C}$ using Le Bail refinement are shown in Fig. S2 (ESI1). After synthesis, the cubic phase of $\mathrm{Li}_{6.5} \mathrm{Al}_{0.25} \mathrm{La}_{2.92} \mathrm{Zr}_{2} \mathrm{O}_{12}$ is identified with two small unknown peaks at around $2 \theta=40^{\circ}$ and $54^{\circ}$. A visible peak associated with $\mathrm{La}_{2} \mathrm{Zr}_{2} \mathrm{O}_{7}$ appears at $500{ }^{\circ} \mathrm{C}$ : this was attributed to a loss of lithium caused by exposure to humidity. Proton and lithium are exchanged and $\mathrm{LiOH}$ is formed and at higher temperature this lack of lithium causes the formation of $\mathrm{La}_{2} \mathrm{Zr}_{2} \mathrm{O}_{7}$ from Al-LLZO main phase. ${ }^{39,55}$ Nevertheless, the cubic space group of the main phase is conserved, and no other impurities are detected at higher temperatures. The structural changes occurring in the phase as a function of temperature are detailed below. As $\mathrm{La}_{2} \mathrm{Zr}_{2} \mathrm{O}_{7}$ amount is not negligeable (approximatively $12 \mathrm{wt} \%$ based on the ratio of main peak intensity of the two phases), diffractograms were analyzed as a two-phase mixture of $\mathrm{Li}_{6.5} \mathrm{Al}_{0.25} \mathrm{La}_{2.92} \mathrm{Zr}_{2} \mathrm{O}_{12}$ and $\mathrm{La}_{2} \mathrm{Zr}_{2} \mathrm{O}_{7}$.

The Al-LLZO cell parameter presented in Fig. 4a does not vary linearly: three temperature ranges can be observed [30-200], [200-500] and [500-1000] ${ }^{\circ} \mathrm{C}$. At $30{ }^{\circ} \mathrm{C}$, the cell parameter $a=12.970(1) \AA$ is in good agreement with the

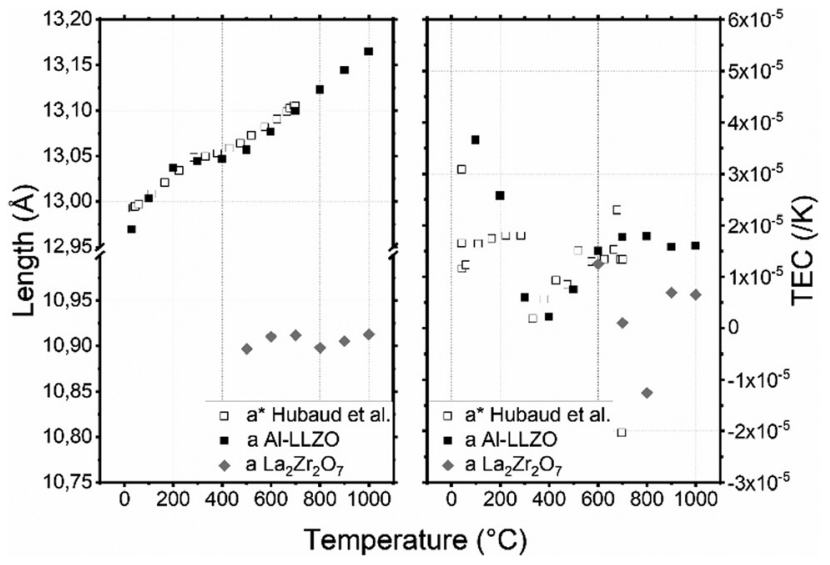

Fig. 4 (a) Lattice parameters of $A L-L L Z O$ and $\mathrm{La}_{2} \mathrm{Zr}_{2} \mathrm{O}_{7}$ depending on the temperature in air and (b) thermal expansion coefficient (TEC) as a function of temperature and the crystallographic axis of $A L-L L Z O$. (*) Data from Hubaud et al. ${ }^{19}$

literature value. ${ }^{56}$ Then, it increases to 13.036(1) A, 13.057(1) and 13.165(1) $\AA$ at 200, 500 and $1000{ }^{\circ} \mathrm{C}$ respectively. The formation of $\mathrm{La}_{2} \mathrm{Zr}_{2} \mathrm{O}_{7}$ is suspected to be responsible for this behavior: the formation of $\mathrm{La}_{2} \mathrm{Zr}_{2} \mathrm{O}_{7}$ may change the phase composition, which may also affect the cell parameters. Hubaud et al. reported the same trend for values without further indication on the formation of $\mathrm{La}_{2} \mathrm{Zr}_{2} \mathrm{O}_{7} .{ }^{19}$ From $500{ }^{\circ} \mathrm{C}$ to the end of the experiment, amount of $\mathrm{La}_{2} \mathrm{Zr}_{2} \mathrm{O}_{7}$ phase seems to be constant, which indicate that there is no further formation. Interestingly, cell parameter of PHASE seems to be constant around 10.90(1) Å between 500 and $1000{ }^{\circ} \mathrm{C}$. Although $\mathrm{La}_{2} \mathrm{Zr}_{2} \mathrm{O}_{7}$ formation is irreversible and the relative intensity is not fully recovered after cooling, the cell parameter of the main phase remains almost the same as $a=12.962(1) \AA$.

Three specific different linear TEC evolutions associated with the three temperature ranges of Al-LLZO [30-200], [200-500] and [500-1000] ${ }^{\circ} \mathrm{C}$ can be observed in Fig. 4 b. In the $[30-200]{ }^{\circ} \mathrm{C}$ range, the TEC decreases from $3.6 \times 10^{-5}$ to $1.8 \times 10^{-6} \mathrm{~K}^{-1}$ which correspond to the Al-LLZO TEC phase before pyrochlore formation. Then the TEC increases to $1.6 \times$ $10^{-5} \mathrm{~K}^{-1}$ at $500{ }^{\circ} \mathrm{C}$ due to pyrochlore formation: Al-LLZO composition might be different at each temperature and so would be the TEC. Finally, after complete formation of the pyrochlore phase, the TEC of Al-LLZO stays almost constant with further increases in temperature. Mean TEC of $\mathrm{La}_{2} \mathrm{Zr}_{2} \mathrm{O}_{7}$ calculated with its cell parameters is $3 \times 10^{-6} \mathrm{~K}^{-1}$. Robert Vassen et al. measured its TEC at $9.1 \times 10^{-6} \mathrm{~K}^{-1} \cdot{ }^{57}$ Inferior value and negative TEC measured at $800{ }^{\circ} \mathrm{C}$ might be due to incertitude as $\mathrm{La}_{2} \mathrm{Zr}_{2} \mathrm{O}_{7}$ is a minor phase and analysis has been done with only 2 peaks at low angle.

\section{Active materials}

Lamellar oxide material. Lamellar oxides $\mathrm{LiNi}_{1 / 3} \mathrm{Mn}_{1 / 3} \mathrm{Co}_{1 / 3} \mathrm{O}_{2}$ (NMC111) and $\mathrm{LiNi}_{0.5} \mathrm{Mn}_{0.3} \mathrm{Co}_{0.2} \mathrm{O}_{2}$ (NMC532) are among the most common oxide-based positive electrode materials. In the discharge state (fully lithiated), NMC111 has all Ni and Co atoms in oxidation states +2 and +3 respectively and NMC532 
has a mix of $+2 /+3$ for $\mathrm{Ni}$ and $+3 /+4$ for Co atoms. As electronic density is different, dilatation and the resulting evolution of cell parameters might be affected. Like NMC, the NCA material has the space group $R \overline{3} \mathrm{~m}$. Diffractogram in the range of temperatures between $30{ }^{\circ} \mathrm{C}$ and $1000{ }^{\circ} \mathrm{C}$ and result of the fit at $30{ }^{\circ} \mathrm{C}$ using Rietveld and Le Bail refinement are shown in Fig. S3-S5 (ESI1) for NMC111, NMC532 and NCA respectively. No impurities appear for NMC111 in the studied temperature range. NCA and NMC532 show no impurities until $800{ }^{\circ} \mathrm{C}$ and $1000{ }^{\circ} \mathrm{C}$ respectively. At these temperatures, the irreversible apparition of other weak intensity peaks attributed to $\mathrm{LiAlO}_{2}$ is observed. However, for the main phase, relative intensities are stable throughout the temperature range. A reaction with the alumina crucible is the main hypothesis for the formation of these impurities. Segregation of phases such as $\mathrm{LiAlO}_{2}$ in alumina doped nickel rich oxide has already been reported. ${ }^{58}$ For the three materials, the same heating treatment was performed in a classical furnace under air in an $\mathrm{Al}_{2} \mathrm{O}_{3}$ crucible. No impurity is found in this case. In the HT-XRD crucible, the amount of powder in contact with the crucible versus the total amount of powder was much more significant than in the classical furnace. So, products of the reaction between the alumina and the powder might be more significant than in the sample heated in the furnace crucible. Fully charged NMC and NCA materials are not tested because they have a lowtemperature transition due to the permanent loss of oxygen: all NMC materials start to change into the disordered spinel form ( $\mathrm{LiMn}_{2} \mathrm{O}_{4}$-type, $F d \overline{3} \mathrm{~m}$ ) at $235^{\circ} \mathrm{C}$ for NMC532, $216{ }^{\circ} \mathrm{C}$ for NMC111 and $256{ }^{\circ} \mathrm{C}$ for NCA. The phase transition occurs at a higher temperature for NCA due to it being in the rock-salt phase. ${ }^{59,60}$

NMC111 and NMC532 have very close cell parameters (Fig. 5a): $a=2.859(1) \AA$ and $c=14.231(1) \AA$ for NMC111 and $a=2.870(1) \AA$ and $c=14.239$ (1) $\AA$ for NMC532 at $30{ }^{\circ} \mathrm{C}$, these values are consistent with those found in literature. ${ }^{61,62}$ They increase to $a=2.923(1) \AA$ and $c=14.231(1) \AA$ for NMC111 and $a=2.929(1) \AA$ and $c=14.546(1) \AA$ for NMC532 at $1000{ }^{\circ} \mathrm{C}$. After cooling, the NMC111 cell parameters are almost identical to the lower temperature values with $a=2.860(1) \AA$ and $c=14.231(1) \AA$ whereas the NMC532 cell parameters increase to $a=2.879(1) \AA$ $(+0.23 \%)$ and $c=14.262(1) \AA(+0.16 \%)$. This increase in the

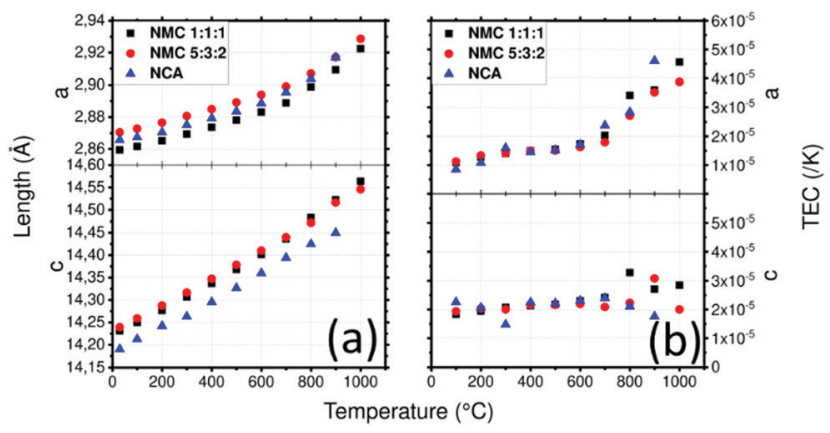

Fig. 5 (a) Lattice parameters of NMC1:1:1, NMC5:3:2 and NCA in air depending on the temperature and (b) thermal expansion coefficient (TEC) as a function of temperature and the crystallographic axis of NMC1:1:1, NMC5:3:2 and NCA. value of the $a$ parameter is not described in literature related to Al doping. ${ }^{63-67}$ However, loss of oxygen during heat treatment could be responsible for these differences as the same tendency was reported for $\mathrm{LiNi}_{0.8} \mathrm{Mn}_{0.1} \mathrm{Co}_{0.1} \mathrm{O}_{2}$ and $\mathrm{LiNi}_{0.6} \mathrm{Mn}_{0.2} \mathrm{Co}_{0.2} \mathrm{O}_{2}$ : above $800{ }^{\circ} \mathrm{C}$ in air or nitrogen. Similar increases of $a$ and $c$ parameters are observed contrasting with that of samples under oxygen flow which recovered their initial cell parameters. ${ }^{68,69}$

NCA has a smaller $c$ and a similar $a$ lattice parameter compared to NMC materials at $30{ }^{\circ} \mathrm{C}$ with $a=2.866(1) \AA$ and $c=14.190(1) \AA$ which is consistent with literature ${ }^{70}$ (Fig. 5a). Lattice parameters of NCA increase to $a=2.917$ (1) $\AA$ and $c=$ 14.450(1) $\AA$ at $900{ }^{\circ} \mathrm{C}$. After cooling, cell parameter $a$ is slightly bigger with $2.873(1) \AA$ and $c$ is recovered with almost no difference (14.192(1) Å).

The average TEC of NMC111 was already measured by dilatometry and was found to be about $1.2-1.3 \times 10^{-5} \mathrm{~K}^{-1} .^{71}$ Here, the TEC depending on the crystallographic orientation is plotted as a function of temperature in Fig. $5 \mathrm{~b}$ and is compared to that of $\mathrm{LiNi}_{0.8} \mathrm{Co}_{0.15} \mathrm{Al}_{0.05} \mathrm{O}_{2}$ (NCA), which has the same structure as NMC532, in order to determine the impact on the TECs of different atomic amounts with different states of oxidation. The results are displayed in Fig. 5b. Lamellar oxides NMC111 and NMC532 show similar results: a linear increase in the TEC along the $a$ direction from $1 \times 10^{-5}$ to $2 \times 10^{-5} \mathrm{~K}^{-1}$ at $700{ }^{\circ} \mathrm{C}$, and then a steeper slope, increasing to $4.6 \times 10^{-5} \mathrm{~K}^{-1}$ for NMC111 and $3.9 \times 10^{-5} \mathrm{~K}^{-1}$ for NMC532 at $1000{ }^{\circ} \mathrm{C}$. Interestingly, at $700{ }^{\circ} \mathrm{C}$, impurities appear for NMC532. For NCA, the TEC along $a$ direction increases linearly from $8 \times$ $10^{-6} \mathrm{~K}^{-1}$ to $1.7 \times 10^{-5} \mathrm{~K}^{-1}$ at $600{ }^{\circ} \mathrm{C}$. A slope break appears, and the TEC raises to $4.6 \times 10^{-5} \mathrm{~K}^{-1}$ at $900{ }^{\circ} \mathrm{C}$. The TEC along the $c$ direction increase linearly from $1.8 \times 10^{-5} \mathrm{~K}^{-1}$ to $2.8 \times 10^{-5} \mathrm{~K}^{-1}$ at $1000{ }^{\circ} \mathrm{C}$ for NMC111 whereas it seems to stay constant around $2 \times 10^{-5} \mathrm{~K}^{-1}$ for NMC532. Along the $c$ direction, the TEC is constant around $2.2 \times 10^{-5} \mathrm{~K}^{-1}$ until $700{ }^{\circ} \mathrm{C}$ after which it decreases to $1.7 \times 10^{-5} \mathrm{~K}^{-1}$ at $900{ }^{\circ} \mathrm{C}$. Fig. S6 (ESI1) shows the mean TECs of NMC111, NMC532 and NCA: interestingly, All NMC-type materials have the same TEC and exhibit similar behaviour with slope breaks around $700{ }^{\circ} \mathrm{C}$. The effect of substitution seems to change the TEC anisotropy. At the beginning of the transition, a loss of oxygen or reactivity with the crucible might be associated with the slope break. ${ }^{72,73}$ This further emphasizes the importance of sintering conditions. Sintering tools or dies and atmospheric conditions must be chosen with caution as contamination and low partial pressure of oxygen (in air, vacuum or strongly reducing graphitic environment) change the TEC and therefore may be responsible for undesired chemical reactions.

Spinel material LNMO. The spinel $\mathrm{LiNi}_{0.5} \mathrm{Mn}_{1.5} \mathrm{O}_{4}$ (LNMO) (space group $F d \overline{3} \mathrm{~m}$ ) is a high potential positive electrode (flat discharge curve at $4.7 \mathrm{~V}) .^{74}$

Diffractogram in the range of temperatures between $30{ }^{\circ} \mathrm{C}$ and $1000{ }^{\circ} \mathrm{C}$ and result of the fit at $30^{\circ} \mathrm{C}$ using Le Bail refinement are shown in Fig. S7 (ESI1). The spinel LMNO shows small impurities which have been identified as the $\mathrm{NiMnO}_{3}$ phase. The crystallographic intensities are stable until $600{ }^{\circ} \mathrm{C}$. At $700{ }^{\circ} \mathrm{C}$, the FWHM decreased due to increases in crystallite size from 
approximately $42 \mathrm{~nm}$ to $160 \mathrm{~nm}$. A new phase is formed at the same time as is indicated by the appearance of new peaks. This reaction has been already highlighted, ${ }^{75}$ it was reported that a two-phase mixture composed of the initial spinel and the rock salt phase, space group $F m \overline{3} m$, was formed. Oxygen loss at high temperature is responsible for the structural changes. On cooling, oxygen is regained reversibly. ${ }^{75}$ After cooling, LNMO samples have more intense peaks, and $\mathrm{NiMnO}_{3}$ impurities have disappeared which suggests that they have probably been integrated into the main phase.

LNMO parameters (Fig. 6a) vary from $a=8.174(1) \AA$ at $30{ }^{\circ} \mathrm{C}$ to $a=8.236(1) \AA$ at $600{ }^{\circ} \mathrm{C}$ where the spinel phase remains the major phase. At $700{ }^{\circ} \mathrm{C}$, the rock-salt phase appears and the spinel phase tends to disappear. The mass percentage of the spinel phase progressively decreases from $100 \%$ at $600{ }^{\circ} \mathrm{C}$ to $7 \%$ at $1000{ }^{\circ} \mathrm{C}$. This reaction might be responsible for the huge increase of the spinel phase cell parameter in this temperature range. At $1000{ }^{\circ} \mathrm{C}, a=8.504(2) \AA$. After cooling, the spinel phase is recovered with a bigger cell parameter $a=8.206(1) \AA$. Integration of the $\mathrm{NiMnO}_{3}$ impurity is a plausible explanation for this increase.

The spinel LMNO shows a TEC (Fig. 6b) of $1 \times 10^{-5} \mathrm{~K}^{-1}$ at $300{ }^{\circ} \mathrm{C}$, it increased to $2 \times 10^{-5} \mathrm{~K}^{-1}$ at $600{ }^{\circ} \mathrm{C}$ where a slope break occurs. This is likely correlated to the loss of oxygen and to the formation of the rock salt phase. Fig. S8 (ESI1) shows the TEC of LMNO with both rock salt and spinel phases on a larger scale: the phase transition induces the huge increase of the TEC up to $1.16 \times 10^{-4} \mathrm{~K}^{-1}$ for the spinel phase and $5.9 \times 10^{-5} \mathrm{~K}^{-1}$ for the rock salt phase. The TEC of LNMO was measured under vacuum. ${ }^{76}$ In order to compare the TECs of these samples, they have been recalculated using eqn (3) from the given cell parameters. Surprisingly, less variations are found in the vacuum case. This is surprising as the release of oxygen under vacuum is expected to be greater than in air and is expected to result in a larger deviation in TEC. As the measurement was recorded up to $700{ }^{\circ} \mathrm{C}$, the transition to the rock salt structure was not reported despite a break in the slope.

Olivine materials. Olivine $\mathrm{LiFePO}_{4}$ (LFP) material is a wellknown positive electrode because its reliability, its low volume expansion upon insertion and its disinsertion of lithium make it a good candidate for ASSBs. ${ }^{77}$ A solid solution exists all along the $\mathrm{LiFe}_{x} \mathrm{Mn}_{1-x} \mathrm{PO}_{4}$ phase diagram where the orthorhombic olivine structure is maintained. $\mathrm{LiFe}_{0.25} \mathrm{Mn}_{0.75} \mathrm{PO}_{4}$ (LFMP),

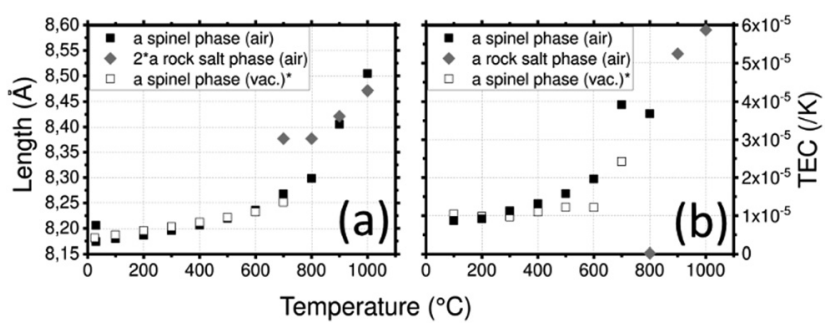

Fig. 6 (a) Lattice parameters of LNMO depending on the temperature and (b) thermal expansion coefficient (TEC) as a function of temperature and the crystallographic axis of LNMO. $\left(^{*}\right)$ Calculated from data of Zeng et al. ${ }^{76}$ where $\mathrm{Fe}$ is partially substituted by Mn presents a higher oxidation voltage with a second plateau due to $\mathrm{Mn}$ at $4.1 \mathrm{~V}^{78}$ Diffractogram in the range of temperatures between $30{ }^{\circ} \mathrm{C}$ and $800{ }^{\circ} \mathrm{C}$ and result of the fit at $30{ }^{\circ} \mathrm{C}$ using Rietveld refinement are shown in Fig. S9 and S10 (ESI1) for LFP and LFMP respectively. LFP and LFMP show no visible impurities (up to $800{ }^{\circ} \mathrm{C}$ ) and broad peaks. Broad peaks are due to nanometer size particles. Particle sizes are calculated to be about $100 \mathrm{~nm}$ and $60 \mathrm{~nm}$ for LFP and LFMP respectively. LFP show a crystallite size increase to above $200 \mathrm{~nm}$ at $800{ }^{\circ} \mathrm{C}$ while LFMP crystallite size begins to increase at $700{ }^{\circ} \mathrm{C}$. In order to characterize the influence of lithium on the cell parameters and the TEC of "olivine" with temperature, HT-XRD is performed on $\mathrm{FePO}_{4}$ heterosite material (delithiated LFP) which has the same space group as LFP and LFMP (space group Pnma). Diffractogram in the range of temperatures between $30{ }^{\circ} \mathrm{C}$ and $800{ }^{\circ} \mathrm{C}$ and result of the fit at $30{ }^{\circ} \mathrm{C}$ using Rietveld refinement are shown in Fig. S11 (ESI1). After delithiation of LFP, FP material shows some small peaks around $2 \theta=18.9,23.5,28$ and $35.3^{\circ}$ ascribed to $\mathrm{Li}$ acetate are visible. These are related improper washing of the material after chemical delithiation of LFP using acetic acid with four main peaks. Unfortunately, a non-reversible phase transition occurs at $600{ }^{\circ} \mathrm{C}$ with $\mathrm{Fe}_{7}\left(\mathrm{PO}_{4}\right)_{6}$ formation due to the partial reduction of $\mathrm{Fe}^{3+}$ to $\mathrm{Fe}^{2+} \cdot{ }^{79,80}$ As the experiment is performed under argon atmosphere, the carbon coating on the particles is likely responsible for this reduction. To increase the thermal stability of FP, using a more oxidizing environment (air) increases the heterosite phase stability to $600{ }^{\circ} \mathrm{C}$ but a trigonal structure (space group $P 3_{1} 21$ ) starts to irreversibly grow even if heterosite remains the main phase.

Cell parameters of LFP (Fig. 7a) are $a=10.321(1) \AA$, $b=6.001(1) \AA$ and $c=4.693(1) \AA$ and those of LFMP are $a=10.414(1) \AA, b=6.074(1) \AA$ and $c=4.728(1) \AA$ at $30{ }^{\circ} \mathrm{C}$. The cell parameters are in good agreement with the literature ${ }^{81}$ and the difference between LFP and LFMP can be explained by the

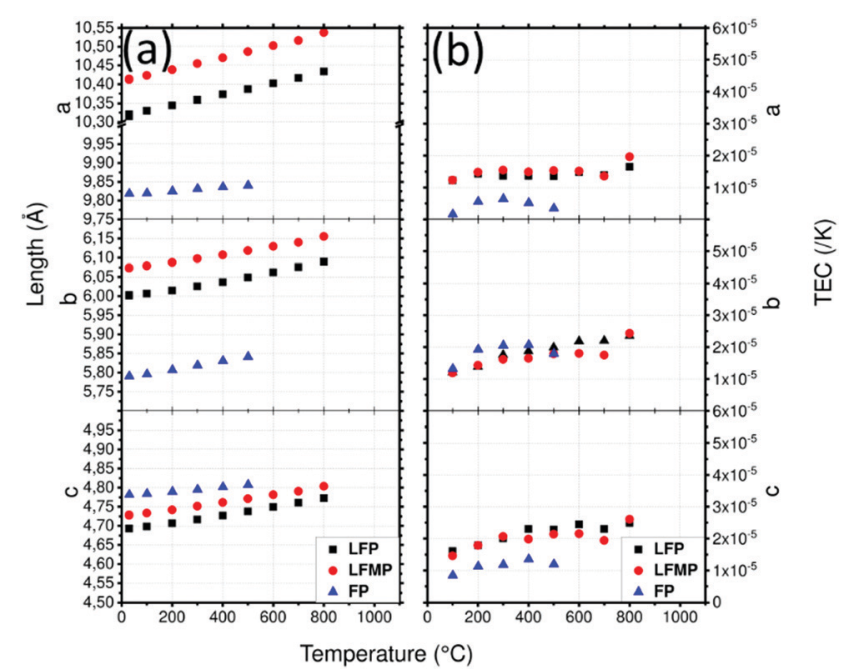

Fig. 7 (a) Lattice parameters of LFP, LFMP and FP in argon atmosphere depending on the temperature and (b) thermal expansion coefficient (TEC) as a function of temperature and the crystallographic axis of LFP, LFMP and FP. 
substitution of Fe by Mn which has a bigger ionic radius, $0.75 \AA$ vs. $0.8 \AA^{82}$ In both cases, the cell parameters increase by approximately $0.11,0.09$ and $0.08 \AA$ for $a, b$ and $c$ respectively. The cell parameters of FP are $a=9.818(1) \AA ̊ n, b=5.790(1) \AA$ and $c=4.781(1) \AA$ at $30{ }^{\circ} \mathrm{C}$ and are also in good agreement with Yamada et al. ${ }^{83}$ They increase to $a=9.840(1) \AA, b=5.841(1) \AA$ and $c=4.807(1) \AA$ at $500{ }^{\circ} \mathrm{C}$ and follow a smoother trend than LFP and LFMP. After cooling, LFP presents almost the same $a$ and $c$ cell parameters while $b$ increases slightly: $a=10.346(1) \AA$, $b=6.003(1) \AA, c=4.693(1) \AA$. LFMP presents the same cell parameters with $a=10.412(1) \AA \quad$ $b=6.073(1) \AA$ and $c=4.727(1) \AA$.

The TEC of LFP (Fig. 7b) along the $c$ direction presents a relatively constant increase from $1.6 \times 10^{-5} \mathrm{~K}^{-1}$ to $2.4 \times$ $10^{-5} \mathrm{~K}^{-1}$ at $600{ }^{\circ} \mathrm{C}$, whereas that of the $b$ direction also increases from $1.2 \times 10^{-5} \mathrm{~K}^{-1}$ to $2.3 \times 10^{-5} \mathrm{~K}^{-1}$. The TEC along the $a$ direction, which is equal to $1.4 \times 10^{-5} \mathrm{~K}^{-1}$, is almost constant throughout the temperature range. Except for LFMP at $T=800{ }^{\circ} \mathrm{C}$, which shows a bigger increase, the TECs are very similar, meaning that Fe substitution by Mn has almost no influence on the thermal expansion of the phase. The delithiated FP material has lower $a$ and $b$ cell parameters and a higher $c$ parameter which is in agreement with literature. ${ }^{81}$ Compared to LFP, FP presents lower TECs. The TEC along the $c$ axis is the most impressive, decreasing from $1.5-2.5 \times 10^{-5} \mathrm{~K}^{-1}$ to $0-5 \times 10^{-6} \mathrm{~K}^{-1}$. However, the slope of the TECs begins to invert at $500{ }^{\circ} \mathrm{C}$ which might be due to the formation of $\mathrm{Fe}_{7}\left(\mathrm{PO}_{4}\right)_{6}$. Fig. S6 (ESI1) shows the mean TECs of LFP, LFMP and FP: LFP and LFMP are almost identical while the TEC of the delithiated sample clearly reduces the mean.

Mixed material based on TEC analysis. The probability of the formation of cracks at the solid electrolyte/active material interface is minimized by reducing the mechanical stress due to thermal dilatation between both materials. According to eqn (2), $\Delta$ TEC $=\mid$ TEC $(\mathrm{CE})-$ TEC(AM $) \mid$ must be as low as possible. Fig. 8 displays $\triangle$ TEC between each AM and CE depending on the temperature. The mean TEC calculated based on the three axes, disregarding anisotropic dilatation, is used for this calculation. This approximation allows the selection of compatible materials from HT-XRD results. As NMC111, MMC532 and NCA have similar Mean TEC as shown in Fig. S6 (ESI1), only NMC532 is represented. For the same reason in Fig. S6 (ESI1) between LFP and LFMP, only LFP is represented. On fig. 8, a red line is drawn at $5.0 \times 10^{-6} \mathrm{~K}^{-1}$ corresponding to $\triangle$ TEC targeted value generally used for SOFC. ${ }^{84}$ Most of the Al-LLZO-AM couples do

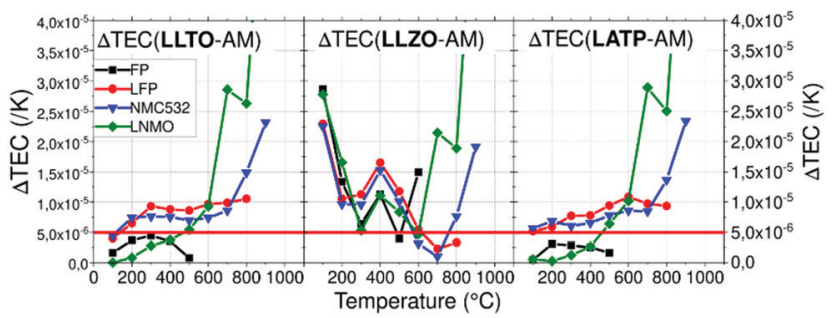

Fig. 8 Thermal expansion coefficient difference $\triangle T E C$ between each AM and CE depending on the temperature. not comply with the target value as the $\triangle$ TEC is varying close to one order of magnitude above $5.0 \times 10^{-6} \mathrm{~K}^{-1}$ all along the temperature range. Solely based on the $\triangle$ TEC and the threshold determined here, no AM would be compatible with Al-LLZO material. This is because the volume expansion of Al-LLZO is somewhat erratic with temperature. This is contrasting with the results found for LLTO and LATP. As the Mean TEC for LLTO and LATP is more regular, variations of $\triangle$ TEC displayed on Fig. S1 (ESI1) are more linear. Most of the $\triangle$ TEC of CE-AM fall slightly above the threshold up to $600{ }^{\circ} \mathrm{C}$. It is particularly true for phosphate-based and layered oxides AM. The case of LNMO is more complex as it reversibly splits into two phases above $600{ }^{\circ} \mathrm{C}$; a huge increase of $\triangle$ TEC is observed beyond that temperature. Still, among all the couples studied here, four $\mathrm{CE} / \mathrm{AM}$ couples have a $\triangle \mathrm{TEC}$ below the target until $500{ }^{\circ} \mathrm{C}$ : FP and LNMO mixed with LLTO or LATP. $500{ }^{\circ} \mathrm{C}$ remains a relatively low temperature though that may not allow for efficient sintering. With a higher threshold $\left(\approx 1.0 \times 10^{-5} \mathrm{~K}^{-1}\right)$, more couples would become compatible up to $800{ }^{\circ} \mathrm{C}$ with a more sensible temperature. However, the use of high sintering temperature also implies that the chemical stability between the materials must be guaranteed.

Using a threshold of $5.0 \times 10^{-6} \mathrm{~K}^{-1}$, chemical stability of mixed CE/AM (CE = LLTO or LATP, AM = LNMO) was investigated by performing XRD after heat treatment. As explained above, FP in heterosite structure is not stable under air at $600{ }^{\circ} \mathrm{C}$ and FP-related impurities start to irreversibly grow even if heterosite remains the main phase at $600{ }^{\circ} \mathrm{C}$. This maximum temperature is relatively low for allowing the efficient sintering of both LATP and LLTO ceramic electrolyte with FP. In that sense, mixture of FP with ceramic electrolytes was not further addressed. The case of LNMO is more interesting. The results are reported in Fig. 9 in the case of LATP and LLTO with LNMO. From XRD, LATP and LNMO are compatible up to $600{ }^{\circ} \mathrm{C}$. If heat treatment is short $(1 \mathrm{H})$,

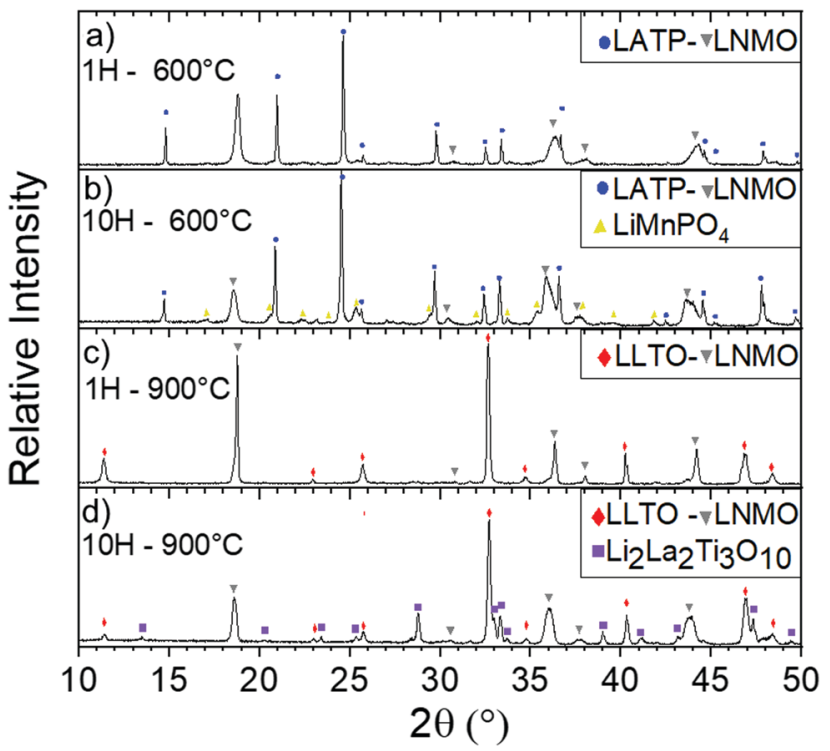

Fig. 9 Diffractograms of mixed LATP and LNMO $50 / 50$ vol\% at $600{ }^{\circ} \mathrm{C}$ after (a) $1 \mathrm{~h}$ and (b) $10 \mathrm{H}$ and mixed LLTO and LNMO 50/50 vol\% at $900{ }^{\circ} \mathrm{C}$ after (c) $1 \mathrm{~h}$ and (d) $10 \mathrm{H}$ 
no impurity is detected but after $10 \mathrm{H}$, a new phase similar to $\mathrm{LiMnPO}_{4}$ appears with small peaks. It means that LATP and LNMO are not thermodynamically stable at this temperature but kinetic is low which allows short treatment. ${ }^{8}$ In that sense Flash sintering using Spark Plasma Sintering (SPS) might be a solution to avoid these reactions as it decreases temperature and time for sintering. Above this temperature, i.e. above the temperature of reversible splitting into spinel plus rock-salt phases, they drastically react together into $\mathrm{LiMnPO}_{4}$ and other phases. ${ }^{85}$ If the heat treatment is performed for only $1 \mathrm{H}$, LLTO and LNMO show no reaction neither up to at least $900{ }^{\circ} \mathrm{C}$, meaning both materials are compatible up to that temperature in those conditions. After longer thermal treatment $(10 \mathrm{H})$ at $900{ }^{\circ} \mathrm{C}$ phases similar to $\mathrm{Li}_{2} \mathrm{La}_{2} \mathrm{Ti}_{3} \mathrm{O}_{10}$ starts to grow. Similarly to the preceding mix, this means that LLTO and LNMO are not thermodynamically stable at $900{ }^{\circ} \mathrm{C}$ but kinetic is low which allows short thermal treatment. Though, the phase splitting of LNMO due to loss of oxygen occurring above $700{ }^{\circ} \mathrm{C}$ might not allow the sintering at higher temperature. This still needs to be clarified experimentally. As oxygen release happens at higher temperature with $\mathrm{O}_{2}$ pure atmosphere, increasing partial pressure of $\mathrm{O}_{2}$ might enhance the TEC stability of the spinel phase. ${ }^{86}$ Further experiments in $\mathrm{O}_{2}$ rich atmosphere are required to confirm our assumption. Moreover, determination of the Young's modulus of the phases might become mandatory at this point.

The thermal compatibility of active material mixed with electrolyte is discussed above without considering other components. However, the need of electronic additives such as carbon or metals and sintering aid (to favor the sintering ${ }^{87-89}$ ) may change these conclusions. Additives used to decrease the sintering temperature ${ }^{9,90,91}$ might act as a buffer regarding constrains with plastic deformation and allow minimal cracks during cooldown after sintering. For example use of plastic behavior sealant material in SOFC (metal or glass-ceramics) improves the resistance toward constraints as brittle fractures are more damaging than plastic deformation. ${ }^{92}$ In the same idea, use of glass-ceramic as sintering additives or metal in the electrode part may help absorbing constraints in ASSBs. Moreover, electronic additive such as carbon in electrode layers might influence the mechanical properties of the layer increasing the flexural strength or fracture toughness by suppression of crack propagation. ${ }^{93}$ On the other hand, they may also prevent ideal sintering as they can act as lubricant. ${ }^{94}$

\section{Conclusions}

In this work, we used HT-XRD in order to reference the TEC depending on crystallographic axis and temperature of various electrolyte and active materials. Minimal mismatch of TEC between materials is required to decrease stress during heat treatment because excess of stress can generate cracks that have disastrous effect on electrochemical performance. All active materials have really similar TEC, in the same range of values $\left(1-2 \times 10^{-5} \mathrm{~K}^{-1}\right)$. Delithiated material FP shows smaller TECs under argon compared to LFP up to $500{ }^{\circ} \mathrm{C}$ where a nonreversible transition occurs which can be increase to $600{ }^{\circ} \mathrm{C}$ under air atmosphere. Use of delithiated active material in solid state batteries during sintering might be a way to reduce TECs mismatch but their lower thermal chemical stability is challenging regarding the densification temperature making it more complicated the assembly of charged solid state batteries for lithium metal application. Solid electrolytes have more diversified TEC and are often more constant. Nevertheless, strong anisotropy of LATP material must be taken in account when sintering as cracks occur above a critical grain size $>0.2 \mu \mathrm{m}$. In order to highlight compatible materials with minimal mismatch of the TEC, $\triangle$ TEC between typical AM have been calculated. The lowest mismatch was found for the couples LATP/FP, LATP/LNMO, LLTO/FP and LLTO/LNMO which are below $5.0 \times 10^{-6} \mathrm{~K}^{-1}$ until $500{ }^{\circ} \mathrm{C}$. On top of the low TEC mismatch up to $500{ }^{\circ} \mathrm{C}$, no thermal degradation of LLTO mixed with LNMO up to $900{ }^{\circ} \mathrm{C}$ during short treatment $(1 \mathrm{H})$ was reported, which is one of the highest reported to our knowledge. Thermal stability of LNMO might be increased by controlling partial pressure of $\mathrm{O}_{2}$ which might stabilize its TEC and improve thermal compatibility with LLTO at higher temperatures. Even if thermal degradation of mixes is often under the sintering temperature of CE, sintering additives might be used in order to densify composite material.

We encourage others to reference TEC of other components (active materials, solid electrolytes, conductive fillers and eventually sintering aid) in order to choose and select compatible materials efficiently. Referencing the Young's modulus is another important thing to predict cracks and use more complex model depending on the architecture of the cell. Beyond that, it will be necessary to consider the stress generated by dilatation of electrodes AM during cycling as it will be critical for the lifetime of the battery.

\section{Conflicts of interest}

There are no conflicts to declare.

\section{Acknowledgements}

The authors gratefully acknowledge the financial support received from the Natural Sciences and Engineering Research Council of Canada (NSERC RDCPJ 528052-18) and Total.

Special thanks to Gabrielle FORAN who proofread the article to correct and improve the English.

\section{Notes and references}

1 G. Zubi, R. Dufo-López, M. Carvalho and G. Pasaoglu, Renewable Sustainable Energy Rev., 2018, 89, 292-308.

2 L. Fan, S. Wei, S. Li, Q. Li and Y. Lu, Adv. Energy Mater., 2018, 8, 1702657.

3 S. El Khakani, J. C. Forgie, D. D. MacNeil and D. Rochefort, J. Electrochem. Soc., 2015, 162, A1432-A1438.

4 Y. Meesala, A. Jena, H. Chang and R.-S. Liu, ACS Energy Lett., 2017, 2, 2734-2751.

5 Y. Tian, T. Shi, W. D. Richards, J. Li, J. C. Kim, S.-H. Bo and G. Ceder, Energy. Environ. Sci., 2017, 10, 1150-1166. 
6 Y. Xiao, Y. Wang, S.-H. Bo, J. C. Kim, L. J. Miara and G. Ceder, Nat. Rev. Mater., 2020, 5, 105-126.

7 Y. Zhu, X. He and Y. Mo, ACS Appl. Mater. Interfaces, 2015, 7, 23685-23693.

8 G. Delaizir, V. Viallet, A. Aboulaich, R. Bouchet, L. Tortet, V. Seznec, M. Morcrette, J.-M. Tarascon, P. Rozier and M. Dollé, Adv. Funct. Mater., 2012, 22, 2140-2147.

9 F. Han, J. Yue, C. Chen, N. Zhao, X. Fan, Z. Ma, T. Gao, F. Wang, X. Guo and C. Wang, Joule, 2018, 2, 497-508.

10 K. Park, B.-C. Yu, J.-W. Jung, Y. Li, W. Zhou, H. Gao, S. Son and J. B. Goodenough, Chem. Mater., 2016, 28, 8051-8059.

11 A. Aboulaich, R. Bouchet, G. Delaizir, V. Seznec, L. Tortet, M. Morcrette, P. Rozier, J.-M. Tarascon, V. Viallet and M. Dollé, Adv. Energy Mater., 2011, 1, 179-183.

12 O. Levit, P. Xu, B. Shvartsev, G. Avioz Cohen, L. Stanciu, Y. Tsur and Y. Ein-Eli, Energy Technol., 2020, 8(12), 2000634, DOI: $10.1002 /$ ente.202000634.

13 P. Xu, W. Rheinheimer, S. N. Shuvo, Z. Qi, O. Levit, H. Wang, Y. Ein-Eli and L. A. Stanciu, ChemElectroChem, 2019, 6, 4576-4585.

14 H. Shen, E. Yi, S. Heywood, D. Y. Parkinson, G. Chen, N. Tamura, S. Sofie, K. Chen and M. M. Doeff, ACS Appl. Mater. Interfaces, 2019, 12, 3494-3501.

15 K. Nagao, M. Nose, A. Kato, A. Sakuda, A. Hayashi and M. Tatsumisago, Solid State Ionics, 2017, 308, 68-76.

16 M.-J. Kim, J.-W. Park, B. G. Kim, Y.-J. Lee, Y.-C. Ha, S.-M. Lee and K.-J. Baeg, Sci. Rep., 2020, 10, 1-11.

17 X. Chen, W. He, L.X. Ding, S. Wang and H. Wang, Energy. Environ. Sci., 2019, 12, 938-944.

18 A. Banerjee, X. Wang, C. Fang, E. A. Wu and Y. S. Meng, Chem. Rev., 2020, 120, 6878-6933.

19 A. A. Hubaud, D. J. Schroeder, B. J. Ingram, J. S. Okasinski and J. T. Vaughey, J. Alloys Compd., 2015, 644, 804-807.

20 S. Majumdar, T. Claar and B. Flandermeyer, J. Am. Ceram. Soc., 1986, 69, 628-633.

21 N. Q. Minh and T. Takahashi, Science and Technology of Ceramic Fuel Cells, 1995, pp. 69-116, DOI: 10.1016/B978044489568-4/50005-0.

22 C. S. Montross, H. Yokokawa and M. Dokiya, Br. Ceram. Trans., 2002, 101, 85-93.

23 J. Malzbender, T. Wakui and R. W. Steinbrech, Fuel Cells, 2006, 6, 123-129.

24 J. Malzbender, R. W. Steinbrech and L. Singheiser, Fuel Cells, 2009, 9, 785-793.

25 Proc. R. Soc. London, Ser. A, 1946, 186, 57-71.

26 C. Georgiadis, Comput. Struct., 1984, 18, 537-549.

27 Y. Hirata, Ceram. Int., 2015, 41, 2706-2713.

28 Y. Hirata and T. Shimonosono, J. Korean Ceram. Soc., 2016, 53, 43-49.

29 K. Fischer and J. R. Seume, 2009, 6.

30 J. R. Rice and M. P. Cleary, Rev. Geophys., 1976, 14, 227-241.

31 S. Shakrawar, J. Pharoah, B. Peppley and S. Beale, ASME International Mechanical Engineering Congress and Exposition, 2010, vol. 5, pp. 983-991.

32 A. Selçuk, G. Merere and A. Atkinson, J. Mater. Sci., 2001, 36, 1173-1182.
33 I. Yamai and T. Ota, J. Am. Ceram. Soc., 1993, 76, 487-491.

34 M. Holzapfel, G. Wendrich, S. Busl and G. Nuspl, US Pat., US2012/0295168A1, 2012.

35 E. B. Fredj, S. Rousselot, L. Danis, T. Bibienne, M. Gauthier, G. Liang and M. J. Dollé, J. Energy Storage, 2020, 27, 101116.

36 D. Lepage, F. Sobh, C. Kuss, G. Liang and S. Schougaard, J. Power Sources, 2014, 256, 61-65.

37 M. Talebi-Esfandarani, S. Rousselot, M. Gauthier, P. Sauriol, G. Liang and M. Dollé, J. Solid State Electrochem., 2016, 20, 1821-1829.

38 C. Ban, Solid State Ionics, 2001, 140, 285-292.

39 A. Paolella, W. Zhu, G. Bertoni, S. Savoie, Z. Feng, H. Demers, V. Gariepy, G. Girard, E. Rivard and N. Delaporte, ACS Appl. Energy Mater., 2020.

40 K. Liu, J.-T. Ma and C.-A. Wang, J. Power Sources, 2014, 260, 109-114.

41 E. McCalla, G. H. Carey and J. R. Dahn, Solid State Ionics, 2012, 219, 11-19.

42 B. H. Toby and R. B. Von Dreele, J. Appl. Crystallogr., 2013, 46(2), 544-549.

43 Y. Inaguma and M. Nakashima, J. Power Sources, 2013, 228, 250-255.

44 F. Aguesse, J. M. López del Amo, V. Roddatis, A. Aguadero and J. A. Kilner, Adv. Mater. Interfaces, 2014, 1.

45 H. Geng, A. Mei, Y. Lin and C. Nan, Mater. Sci. Eng., B, 2009, 164, 91-95.

46 Y. Inaguma, C. Liquan, M. Itoh, T. Nakamura, T. Uchida, H. Ikuta and M. Wakihara, Solid State Commun., 1993, 86, 689-693.

47 Y. Cheng, Z. Bi, A. Huq, M. Feygenson, C. Bridges, M. Paranthaman and B. J. Sumpter, J. Mater. Chem. A, 2014, 2, 2418-2426.

48 O. Bohnke, H. Duroy, J.-L. Fourquet, S. Ronchetti and D. Mazza, Solid State Ionics, 2002, 149, 217-226.

49 Y. Harada, Y. Hirakoso, H. Kawai and J. Kuwano, Solid State Ionics, 1999, 121, 245-251.

50 T. Hupfer, E. C. Bucharsky, K. G. Schell, A. Senyshyn, M. Monchak, M. J. Hoffmann and H. Ehrenberg, Solid State Ionics, 2016, 288, 235-239.

51 M. Monchak, T. Hupfer, A. Senyshyn, H. Boysen, D. Chernyshov, T. Hansen, K. G. Schell, E. C. Bucharsky, M. J. Hoffmann and H. Ehrenberg, Inorg. Chem., 2016, 55, 2941-2945.

52 H. Buschmann, J. Dolle, S. Berendts, A. Kuhn, P. Bottke, M. Wilkening, P. Heitjans, A. Senyshyn, H. Ehrenberg, A. Lotnyk, V. Duppel, L. Kienle and J. Janek, Phys. Chem. Chem. Phys., 2011, 13, 19378-19392.

53 S. G. Kang and D. S. Sholl, J. Phys. Chem. C, 2014, 118, 17402-17406.

54 Q. Liu, Z. Geng, C. Han, Y. Fu, S. Li, Y.-B. He, F. Kang and B. Li, J. Power Sources, 2018, 389, 120-134.

55 G. Larraz, A. Orera and M. L. Sanjuán, J. Mater. Chem. A, 2013, 1, 11419-11428.

56 N. Rosenkiewitz, J. Schuhmacher, M. Bockmeyer and J. Deubener, J. Power Sources, 2015, 278, 104-108.

57 R. Vassen, X. Cao, F. Tietz, D. Basu and D. Stöver, J. Am. Ceram. Soc., 2000, 83, 2023-2028. 
58 L. Croguennec, Y. Shao-Horn, A. Gloter, C. Colliex, M. Guilmard, F. Fauth and C. Delmas, Chem. Mater., 2009, 21, 1051-1059.

59 K. W. Nam, S. M. Bak, E. Hu, X. Yu, Y. Zhou, X. Wang, L. Wu, Y. Zhu, K. Y. Chung and X. Q. Yang, Adv. Funct. Mater., 2013, 23, 1047-1063.

60 S.-M. Bak, E. Hu, Y. Zhou, X. Yu, S. D. Senanayake, S.-J. Cho, K.-B. Kim, K. Y. Chung, X.-Q. Yang and K.-W. Nam, ACS Appl. Mater. Interfaces, 2014, 6, 22594-22601.

61 R. Weber, C. R. Fell, J. Dahn and S. Hy, J. Electrochem. Soc., 2017, 164, A2992-A2999.

62 C. Yang, X. Zhang, M. Huang, J. Huang and Z. Fang, ACS Appl. Mater. Interfaces, 2017, 9, 12408-12415.

63 L. Croguennec, J. Bains, J. Bréger, C. Tessier, P. Biensan, S. Levasseur and C. Delmas, J. Electrochem. Soc., 2011, 158, A664.

64 F. Zhou, X. Zhao, Z. Lu, J. Jiang and J. Dahn, Electrochem. Commun., 2008, 10, 1168-1171.

65 D. Aurbach, O. Srur-Lavi, C. Ghanty, M. Dixit, O. Haik, M. Talianker, Y. Grinblat, N. Leifer, R. Lavi and D. T. Major, J. Electrochem. Soc., 2015, 162, A1014-A1027.

66 T. E. Conry, A. Mehta, J. Cabana and M. M. Doeff, Chem. Mater., 2012, 24, 3307-3317.

67 F. Dogan, J. T. Vaughey, H. Iddir and B. Key, ACS Appl. Mater. Interfaces, 2016, 8, 16708-16717.

68 M. S. Idris and A. West, J. Electrochem. Soc., 2012, 159, A396.

69 S.-W. Lee, H. Kim, M.-S. Kim, H.-C. Youn, K. Kang, B.-W. Cho, K. C. Roh and K.-B. Kim, J. Power Sources, 2016, 315, 261-268.

70 K. D. R. Ekawati, A. P. Sholikah, C. S. Yudha, H. Widiyandari and A. Purwanto, 5th International Conference on Electric Vehicular Technology (ICEVT), IEEE, 2018, pp. 57-61.

71 E. J. Cheng, K. Hong, N. J. Taylor, H. Choe, J. Wolfenstine and J. Sakamoto, J. Eur. Ceram. Soc., 2017, 37, 3213-3217.

72 G. C. Kostogloudis and C. Ftikos, J. Eur. Ceram. Soc., 1999, 19, 497-505.

73 D. Marrero-López, J. Peña-Martínez, J. Ruiz-Morales, M. MartínSedeño and P. Núñez, J. Solid State Chem., 2009, 182, 1027-1034.

74 Q. Zhong, A. Bonakdarpour, M. Zhang, Y. Gao and J. Dahn, J. Electrochem. Soc., 1997, 144, 205-213.

75 D. Pasero, N. Reeves, V. Pralong and A. R. West, J. Electrochem. Soc., 2008, 155(4).
76 L. Zeng, Y. Chen, W. He and L. Nong, Powder Diffr., 2008, 23, 224-227.

77 J. B. Goodenough, A. K. Padhi, K. S. Nanjundaswamy and C. Masquelier, US Pat., 5910382, 1999.

78 J. Hong, F. Wang, X. Wang and J. Graetz, J. Power Sources, 2011, 196, 3659-3663.

79 C. Delacourt, P. Poizot, J.-M. Tarascon and C. Masquelier, Nat. Mater., 2005, 4, 254-260.

80 S. P. Ong, A. Jain, G. Hautier, B. Kang and G. Ceder, Electrochem. Commun., 2010, 12, 427-430.

81 A. Yamada, Y. Kudo and K.-Y. Liu, J. Electrochem. Soc., 2001, 148(7), 148.

82 R. D. Shannon, Acta Crystallogr., Sect. A: Cryst. Phys., Diffr., Theor. Gen. Crystallogr., 1976, 32, 751-767.

83 A. Yamada, H. Koizumi, N. Sonoyama and R. Kanno, Electrochem. Solid-State Lett., 2005, 8, A409-A413.

84 N. Mahato, A. Banerjee, A. Gupta, S. Omar and K. Balani, Prog. Mater. Sci., 2015, 72, 141-337.

85 L. Miara, A. Windmüller, C.-L. Tsai, W. D. Richards, Q. Ma, S. Uhlenbruck, O. Guillon and G. Ceder, ACS Appl. Mater. Interfaces, 2016, 8, 26842-26850.

86 B. Aktekin, M. Valvo, R. I. Smith, M. H. Sørby, F. Lodi Marzano, W. Zipprich, D. Brandell, K. Edström and W. R. Brant, ACS Appl. Energy Mater., 2019, 2, 3323-3335.

87 R.-H. Shin, S. I. Son, Y. S. Han, Y. Do Kim, H.-T. Kim, S.-S. Ryu and W. Pan, Solid State Ionics, 2017, 301, 10-14.

88 T. Zhu, Y. Lin, Z. Yang, D. Su, S. Ma, M. Han and F. Chen, J. Power Sources, 2014, 261, 255-263.

89 B. Xu, B. Huang, H. Liu, H. Duan, S. Zhong and C.-A. Wang, Electrochim. Acta, 2017, 234, 1-6.

90 Z. M. Grady, K. Tsuji, A. Ndayishimiye, J. Hwan-Seo and C. A. Randall, ACS Appl. Energy Mater., 2020, 3(5), 4356-4366.

91 P. Birke, F. Salam, S. Döring and W. Weppner, Solid State Ionics, 1999, 118, 149-157.

92 J. W. Fergus, J. Power Sources, 2005, 147, 46-57.

93 K. Nakano, A. Kamiya, H. Ogawa and Y. J. Nishino, J. Ceram. Soc. Jpn., 1992, 100, 472-475.

94 D. Chung, J. Mater. Sci., 2002, 37, 1475-1489. 